\title{
Sulfide survival and diamond genesis during formation and evolution of Archaean subcontinental lithosphere: Kaapvaal vs Slave
}

\author{
Sonja Aulbach ${ }^{1,}$ Thomas Stachel ${ }^{1}$, Robert A. Creaser ${ }^{1}$, Larry. M. Heaman ${ }^{1}$, Steven B. \\ Shirey $^{2}$, Karlis Muehlenbachs ${ }^{1}$, David Eichenberg ${ }^{3}$, Jeff W. Harris ${ }^{4}$ \\ ${ }^{I}$ Earth \& Atmospheric Sciences, University of Alberta, Edmonton AB, Canada \\ ${ }^{2}$ Department of Terrestrial Magnetism, Carnegie Institution of Washington, Washington DC, USA \\ ${ }^{3}$ Diavik Diamond Mines, Yellowknife, NT, Canada \\ ${ }^{4}$ Department of Geographical and Earth Sciences, University of Glasgow, Glasgow, UK
}

\section{Introduction}

We released and characterized sulfide inclusions from 50 diamonds from the Lac de Gras kimberlites (Diavik Diamond Mines) in the central Slave Craton to obtain the first diamond formation ages for this locality. Combining these results with a previous similar study on exclusively peridotitic sulfide inclusions from the nearby Panda kimberlite allows a preliminary comparison with the formation ages and conditions of diamonds from the well-studied Kaapvaal Craton.

\section{Methods}

After release of sulfide inclusions by diamond crushing, the nitrogen abundances and aggregation states of the diamonds were determined by Fourier Transform Infra-Red spectroscopy (FTIR). Carbon isotope data were also obtained by total combustion. For the Re-Os analyses of the sulphide inclusions, the methodology and analytical routines at University of Alberta closely follow those developed by Shirey and co-workers (Pearson et al. 1998; Richardson et al. 2001). Rhenium and Os were purified from spiked solutions of single sulfides and each fraction was loaded onto a Pt filament and analysed by Negative Thermal Ionisation Mass Spectrometry (Creaser et al., 1991) on a Micromass multicollector Sector 54 mass spectrometer, operated by single collector peakhopping using an ETP electron multiplier (pulse counting mode). Rhenium and Os concentrations were obtained by isotope dilution. Total Os blanks (including filament blanks) were on average $9 \mathrm{fg}$ with a $50 \%$ uncertainty; Re blanks averaged $100 \mathrm{fg}$ with a $50 \%$ uncertainty. During the course of the measurements (November 2007 to March 2008) repeated analysis of $1 \mathrm{pg}$ of the in-house standard AB-2 yielded ${ }^{187} \mathrm{Os} /{ }^{188}$ Os of $0.1064 \pm 0.0011(1 \sigma)$.

\section{Results}

Based on the $(\mathrm{Ni}+\mathrm{Co}) / \mathrm{Fe}$ ratios of their sulfide inclusions, diamonds can be assigned to an eclogitic (average $\mathrm{Ni}+\mathrm{Co} / \mathrm{Fe}: 0.09$ ) or a peridotitic suite (0.82).
The sulphide-bearing diamonds are consistent with the general A154S inclusion population in that they have mantle-like $\delta{ }^{13} \mathrm{C}(-4.9 \pm 0.6 \% 0 \quad 1 \sigma)$ and low $\mathrm{N}$ aggregation states at a given $\mathrm{N}$ content $(\% \mathrm{~N}$ in $\mathrm{B}$ centres $=8 \pm 10 \% ; \mathrm{N}=575 \mathrm{ppm} \pm 315)$. However, the proportion of eclogitic $(\sim 80 \%)$ and peridotitic $(\sim 20 \%)$ sulfide inclusions contrasts with the $\sim 90 \%$ peridotitic silicate-inclusion population (Donnelly et al., 2007). Eclogitic sulfide-included diamonds have higher $\mathrm{N}$ contents (average of $730 \mathrm{ppm}$ ) yet lower aggregation states $(5 \% \mathrm{~N}$ as $\mathrm{B})$ than peridotitic sulfides $(278 \mathrm{ppm}$, $19 \%$ as B) indicating distinct mantle residence temperatures and/or times as well as source fluids. Reentrant cubes, which represent a morphological subpopulation ( $26 \%$ of all stones) of the Lac de Gras diamonds related to rapid diamond growth, are generally devoid of silicate inclusions (Donnelly et al. 2007) but contain sulfides of exclusively eclogitic paragenesis.

Sulfides in nine eclogitic diamonds were large enough to perform Re-Os isotope analysis. Of these, sulfides in re-entrant cubes $(\mathrm{N}=4)$ have distinctly lower Re and Os contents (avg 280 and $23 \mathrm{ppb}$, respectively) and higher Re-Os ratios (13.3) than those in the other eclogitic stones (520 and $290 \mathrm{ppb}$, respectively; $\mathrm{Re} / \mathrm{Os}=7.1$ ). Peridotitic sulfides in seven diamonds contain on average $190 \mathrm{ppb} \operatorname{Re}$ and $18.5 \mathrm{ppm}$ Os $(\mathrm{Re} / \mathrm{Os}=0.06)$.

The Re-Os isotope diagram shows that most eclogitic sulfide inclusions lie on age arrays (1.8 and $2.2 \mathrm{Ga}$; Fig. 1a) coincident with a number of Proterozoic events in the Slave craton including arc- and continentcontinent collision. The similarity in the Re-Os eclogitic sulfide inclusion ages obtained in this study and Lu-Hf whole-rock eclogite ages (Schmidberger et al., 2007) support a link between Paleoproterozoic eclogite and eclogitic diamond formation at Diavik. Similar Proterozoic eclogitic diamond formation was previously proposed for the Kaapvaal craton (Pearson et al., 1998; Richardson et al., 2001). Figure 1a also shows that the sulfides from re-entrant cubes may form their own array with distinct high $\mathrm{Re} / \mathrm{Os}$ and ${ }^{187} \mathrm{Os} /{ }^{188} \mathrm{Os}$, potentially lower slope (=age) and high 


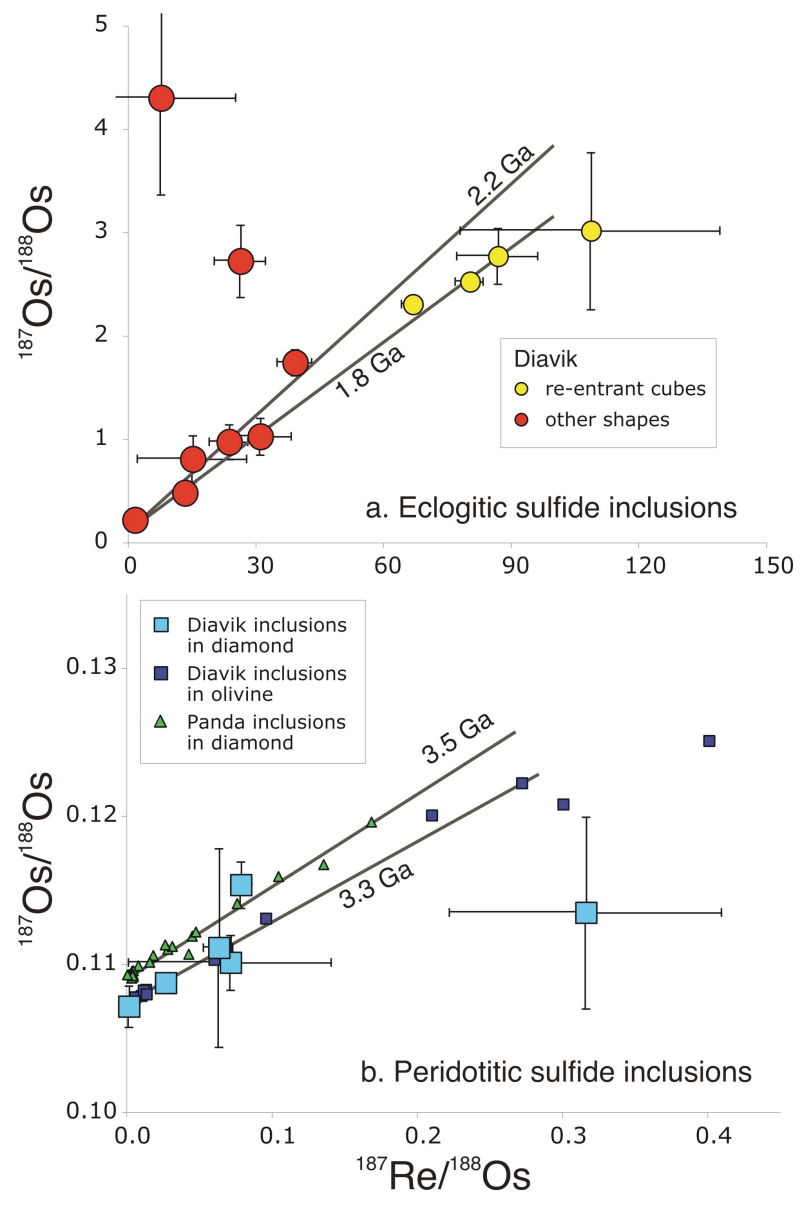

Fig. 1 Re-Os isotope diagram for a. eclogitic and b. peridotitic sulfide inclusions in diamonds from Diavik kimberlite A154S. Shown for comparison in a. are two reference isochrons $(2.2$ and $1.8 \mathrm{Ga})$ and in b. sulfide isochronous inclusions in xenolithic and xenocrystic olivine (Aulbach et al., 2004) and in diamonds from the nearby Panda mine (Westerlund et al., 2006).

initial ${ }^{187} \mathrm{Os} /{ }^{188} \mathrm{Os}$, but these data are as yet inconclusive.

In contrast, sulfide inclusions in most peridotitic diamonds overlap with 3.5 to $3.3 \mathrm{Ga}$ age arrays previously determined for sulfide inclusions in olivine at Diavik (Aulbach et al., 2004) and in diamonds from the nearby Panda mine (Westerlund et al., 2006). Older ages for peridotitic diamonds are consistent with their higher $\mathrm{N}$ aggregation states at a given $\mathrm{N}$ content.

\section{Discussion}

Comparison of diamond formation ages in the Slave and in the Kaapvaal cratons (the latter summarized in Shirey et al., 2004; Stachel and Harris, 2008) indicate that diamond formation beneath the two cratons was fundamentally different:

(1) Earliest diamond formation in the Kaapvaal Craton $(3.3 \mathrm{Ga})$ followed earliest lithosphere nucleation by several $100 \mathrm{Ma}(3.7 \mathrm{Ga}$; review in Shirey et al., 2004) whereas in the central Slave Craton diamond formation (Westerlund et al., 2006; this study) appears to have been coeval with lithosphere formation ca 3.5-3.3 Ga ago (Aulbach et al., 2004).

(2) Despite the general abundance of peridotitic silicate inclusions, peridotitic sulfide inclusions in the Kaapvaal are rare and linked to relatively young diamond formation (Pearson et al., 1998; Aulbach et al., subm.) whereas in the central Slave there is a sizable population that is of Paleoarchaean age (Westerlund et al. 2006; this study).

(3) Both cratons show an abundance of inferred subduction-related eclogitic sulfide inclusions in diamonds whereas for the silicate inclusion suite the proportion of peridotitic inclusions is generally higher (review in Shirey et al. 2004; this study).

These observations can be linked to conditions during formation of the subcontinental lithospheric mantle (SCLM) and subsequent tectonothermal events.

\section{Kaapvaal}

The absence of sulfide-included diamonds as old as the oldest lithosphere in the Kaapvaal Craton could be a consequence of the destruction of older peridotitic diamonds during Proterozoic tectonothermal events (continent collision and subduction). However, such events have also been documented in the Slave craton, where an ancient peridotitic sulfide-included diamond population is preserved, as noted above.

Conditions during formation of the Kaapvaal lithosphere (3.7 to $3.2 \mathrm{Ga}$ ) may have been extreme (hotter, larger melting intervals), as gauged by highly depleted olivine and garnet compositions (Stachel and Harris 2008), leading to formation of an initially diamond-unfriendly and sulfur-undersaturated, hot lithosphere. Because the sulfur content of mantle melts at sulfide saturation increases both with decreasing pressure (strong effect) and increasing temperature (weaker effect) (Liu et al., 2007), sulfide exhaustion in residual mantle may have been achieved either by melting to low pressures (MOR-type setting) followed by thickening of the SCLM during accretionary processes, or during melt extraction at excess mantle temperatures (>ambient mantle), which would imply a high-pressure origin of the SCLM.

The mode of SCLM formation (low vs high-pressure depletion) is still unresolved: conflicting evidence for high-pressure melt removal indicated inter alia by high Mg-numbers in olivine (Herzberg, 1999) and lowpressure melt removal required by high $\mathrm{Cr} / \mathrm{Al}$ in cratonic garnet peridotites (Stachel et al. 1998) cannot be reconciled with currently available experimental data. Regardless, the antiquity of silicate-included peridotitic diamonds requires that the SCLM was thick and cool after only a few $100 \mathrm{Ma}$ (Richardson et al. 1984). Yet, for the Kaapvaal, sulfide bearing peridotitic diamonds are very rare and significantly younger $(<1$ Ga; Pearson et al. 1998; Aulbach et al. subm.). 
Peridotitic sulfides in mantle xenoliths and xenocrysts document repeated episodes of sulfide re-introduction into the lithosphere accompanying metasomatism (Griffin et al. 2004). Thus, the scarcity of sulfideincluded peridotitic diamonds suggests that these events were only rarely conducive to diamond growth.

\section{Slave}

In the Slave Craton, the lithosphere is stratified, with an ultradepleted, mainly harzburgitic shallow layer to $\sim 145 \mathrm{~km}$ that hosts the $3.5 \mathrm{Ga}$ peridotitic sulfideincluding diamonds with a suggested subduction origin (Westerlund et al., 2006) and a mildly depleted deep predominantly lherzolitic layer to $\sim 220 \mathrm{~km}$, the latter thought to be subcreted from a plume originating in the lower mantle (Griffin et al., 1999). Material originating from a thermal boundary layer in the lower mantle would be expected to have high excess temperatures at upper mantle depth. Corresponding melts would have been picritic or komatiitic and probably sulfide undersaturated at source (e.g., Mavrogenes and O'Neill 1999). This scenario of a completely sulfur-depleted melting residue as a protolith for the deep Slave SCLM contrasts with the abundance of Mesoarchaean peridotitic sulfides both in peridotites (Aulbach et al., 2004) and in diamonds (Westerlund et al., 2006) and could indicate that fertile mantle was more widespread as a diamond source.

Upwelling mantle forming the less depleted deep lithospheric mantle would have been stalled by the ultradepleted pre-existing lithosphere at ca $145 \mathrm{~km}$ depth such that lower melting intervals (compared to melting to shallow levels) would have been realized. Though still substantial, lower degrees of melt removal from this mantle layer would be consistent with higher average $\mathrm{Ca}$ contents of garnets in diamonds (Stachel and Harris 2008) and may have allowed residual sulfide preservation. It may also explain the nearabsence of komatiites in the Slave Craton (Bleeker et al. 1999). Alternatively, peridotitic diamond formation during SCLM thickening by accretionary processes (Westerlund et al., 2006) would fit these observations. Either way, contrary to the Kaapvaal Craton, conditions of SCLM formation in the Slave were such that abundant sulfide-included peridotitic diamonds formed penecontemporaneously with the SCLM.

The abundance of inferred subduction-related diamonds with eclogitic sulfide inclusions in both the Kaapvaal and the Slave Cratons contrasts with the silicate inclusion suite where peridotitic inclusions are more frequent. Thus, hydrated slabs appear to represent a fertile source of C-O-H-S fluids for sulfide-included diamond formation subsequent to SCLM formation.

\section{References}

Aulbach, S., Griffin, W.L., Pearson, N.J., O'Reilly, S.Y., Kivi, K., 2004. Mantle formation and evolution,
Slave Craton: constraints from HSE abundances and $\mathrm{Re}-\mathrm{Os}$ isotope systematics of sulfide inclusions in mantle xenocrysts. Chemical Geology, 208, 61-88.

Aulbach, S., Shirey, S.B., Stachel, T., Creighton, S., Muehlenbachs, K., Harris, J.W., (2008) Diamond formation episodes at the southern margin of the Kaapvaal Craton: Re-Os systematics of sulfide inclusions from the Jagersfontein Mine. Contributions to Mineralogy and Petrology (in review).

Bleeker, W., Ketchum, J.W.F., Jackson, V.A., Villeneuve, M., 1999. The Central Slave Basement Complex. Part I: Its structural topology and autochthonous core. Canadian Journal of Earth Sciences, 36, 1083-1109.

Creaser, R.A., Papanastassiou, D.A., Wasserburg, G.J., 1991. Negative thermal ion mass spectrometry of osmium, rhenium, and iridium. Geochimica et Cosmochimica Acta, 55, 397-401.

Donnelly, C.L., Stachel, T., Creighton, S., Muehlenbachs, K., Whiteford, S., 2007. Diamonds and their mineral inclusions from the A154 South pipe, Diavik Diamond Mine, Northwest Territories, Canada. Lithos, 98, 160-176.

Griffin, W.L., Graham, S., O’Reilly, S.Y., Pearson, N.J., 2004. Lithosphere evolution beneath the Kaapvaal Craton: Re-Os systematics of sulfides in mantlederived peridotites. Chemical Geology, 208, 95-215.

Liu Y., Samaha N.-T., Baker D.R., 2007. Sulfur concentration at sulfide saturation (SCSS) in magmatic silicate melts. Geochimica et Cosmochimica Acta, 71, 1783-1799

Pearson, D.G., Shirey, S.B., Harris, J.W., Carlson, R.W., 1998. Sulfide inclusions in diamonds from the Koffiefontein kimberlite, S. Africa: constraints on diamond ages and mantle Re-Os systematics. Earth and Planetary Science Letters, 160, 311-326.

Richardson, S.H., Gurney, J.J., Erlank, A.J., Harris, J.W., 1984 Origin of diamonds in old enriched mantle. Nature, 310, 198-202.

Richardson, S.H., Shirey, S.B., Harris, J.W., Carlson, R.W., 2001. Archean subduction recorded by Re-Os isotopes in eclogitic sulfide inclusions in Kimberley diamonds. Earth and Planetary Science Letters, 191, 257-266.

Schmidberger, S.S., Simonetti, A., Heaman, L.M., Creaser, R.A., and Whiteford, S., 2007. Lu-Hf, in-situ Sr and $\mathrm{Pb}$ isotope and trace element systematics for mantle eclogites from the Diavik diamond mine: Evidence for Paleoproterozoic subduction beneath the Slave craton, Canada. Earth and Planetary Science letters, $254,55-68$

Shirey, S.B., Richardson, S.H., Harris, J.W., 2004. Integrated models of diamond formation and craton evolution. Lithos, 77, 923-944.

Stachel, T., Harris, J.W., 2008. The origin of cratonic diamonds - constraints from mineral inclusions. Ore Geology Reviews (doi:10.1016/j.oregeorev.2007. 05.002).

Westerlund, K.J., Shirey, S.B., Richardson, S.H., Carlson, R.W., Gurney, J.J., Harris, J.W., 2006. A subduction wedge origin for Paleoarchean peridotitic diamonds and harzburgites from the Panda kimberlite, Slave craton: evidence from Re-Os isotope systematics. Contributions to Mineralogy and Petrology, 152, 275294. 